\title{
Insertion Sequence- and Tandem Repeat-Based Genotyping Techniques for Xanthomonas citri pv. mangiferaeindicae
}

\author{
O. Pruvost, C. Vernière, K. Vital, F. Guérin, E. Jouen, F. Chiroleu, N. Ah-You, and L. Gagnevin
}

First, second, third, fourth, fifth, seventh, and eighth authors: research plant pathologists, and sixth author: statistician, CIRAD, UMR Peuplements Végétaux et Bioagresseurs en Milieu Tropical CIRAD-Université de la Réunion, Pôle de Protection des Plantes, 7, chemin de l'Irat, 97410 Saint Pierre, Réunion, France.

Accepted for publication 7 February 2011.

\begin{abstract}
Pruvost, O., Vernière, C., Vital, K., Guérin, F., Jouen, E., Chiroleu, F., AhYou, N., and Gagnevin, L. 2011. Insertion sequence- and tandem repeatbased genotyping techniques for Xanthomonas citri pv. mangiferaeindicae. Phytopathology 101:887-893.

Molecular fingerprinting techniques that have the potential to identify or subtype bacteria at the strain level are needed for improving diagnosis and understanding of the epidemiology of pathogens such as Xanthomonas citri pv. mangiferaeindicae, which causes mango bacterial canker disease. We developed a ligation-mediated polymerase chain reaction targeting the IS1595 insertion sequence as a means to differentiate pv. mangiferaeindicae from the closely related pv. anacardii (responsible for cashew bacterial spot), which has the potential to infect mango but not to

cause significant disease. This technique produced weakly polymorphic fingerprints composed of $\approx 70$ amplified fragments per strain for a worldwide collection of X. citri pv. mangiferaeindicae but produced no or very weak amplification for pv. anacardii strains. Together, 12 tandem repeat markers were able to subtype $X$. citri pv. mangiferaeindicae at the strain level, distinguishing 231 haplotypes from a worldwide collection of 299 strains. Multilocus variable number of tandem repeats analysis (MLVA), IS1595-ligation-mediated polymerase chain reaction, and amplified fragment length polymorphism showed differences in discriminatory power and were congruent in describing the diversity of this strain collection, suggesting low levels of recombination. The potential of the MLVA scheme for molecular epidemiology studies of $X$. citri pv. mangiferaeindicae is discussed.
\end{abstract}

Two pathovars of the plant-pathogenic bacterial species Xanthomonas citri were reported as putative mango (Mangifera indica L.) pathogens (5). Xanthomonas citri pv. mangiferaeindicae is the causal agent of mango bacterial canker (MBC, synonym mango bacterial black spot). This pathogen severely affects most commercial cultivars in the Old World and is a serious threat for industries in Central and South America, which have become major mango exporters (e.g., Mexico, Brazil, and Peru ranked second, third, and fourth, respectively, in 2007 world trade) (http://faostat.fao.org/site/535/DesktopDefault.aspx?PageID=535) . Under climatic conditions favoring $\mathrm{MBC}$, the pathogen can cause fruit losses of up to $85 \%$ (36). X. citri pv. anacardii has solely been reported in Brazil to date. This pathogen is primarily pathogenic to cashew (Anacardium occidentale L.) but also casually infects mango (4). On mango, the morphology of leaf and fruit symptoms can be used for presumptive pathovar identification; however, laboratory tests are required for confirmation. Both pathovars produce creamy white bacterial colonies, which is atypical for xanthomonads. This means they cannot be routinely distinguished on the basis of their morphological characteristics $(31,37)$. Molecular tools used so far for these two bacteria, amplified fragment length polymorphism (AFLP) and multilocus sequence analysis (MLSA), were useful for assigning strains at the species or pathovar level (5). However, there is a need for molecular identification techniques that could be applied for more routine use and which are less

Corresponding author: O. Pruvost; E-mail address: olivier.pruvost@ cirad.fr

* The $e$-Xtra logo stands for "electronic extra" and indicates that there are two supplementary tables available online.

doi:10.1094/PHYTO-11-10-0304

(C) 2011 The American Phytopathological Society labor intensive and faster than pathogenicity assays (i.e., the reference technique for assigning plant pathogenic bacteria to pathovars) (15).

Genotyping techniques for deciphering the epidemiology of bacterial plant pathogens have been of very limited use to date. Molecular fingerprints based on restriction fragment length polymorphism (RFLP), repetitive sequence polymerase chain reaction (rep-PCR), or AFLP and used for analyzing the diversity of xanthomonads on a large geographical scale (worldwide, within a continent, or within part of a continent) were often suggestive of long-distance migration events, which are probably due to the international movement of contaminated propagative plant material $(3,7,20)$. Fingerprinting techniques were also used on smaller scales for optimizing the deployment of monogenic resistance genes $(6,51)$ or for analyzing migration events $(21,41)$. Recently, alternative typing methods targeting tandem repeats or mobile elements such as insertion sequences were developed to achieve satisfactory discriminatory power necessary for typing populations of the closely related $X$. citri pv. citri, a moderately polymorphic bacterium (i.e., a bacterium for which multilocus sequence typing lacks discriminatory power) at variable spatial scales $(8-10,27)$. These studies emphasized the high discriminatory power of multilocus variable number of tandem repeats analysis (MLVA), which makes this technique suitable for epidemiological analyses at rather small spatial or temporal scales. MLVA has become increasingly popular for molecular typing of bacteria $(48,49)$. MLVA schemes were powerful for epidemiological analyses (i.e., inoculum tracking) of several human bacterial pathogens, such as Bacillus anthracis, Escherichia coli, Mycobacterium tuberculosis, and Yersinia pestis $(12,30,43)$. This technique also has the potential to address questions of population genetics (47). Similarly, insertion sequence-based typing has proven useful for the epidemiological typing of several pathogenic bacteria, including $M$. tuberculosis $(26,34,40)$. 
Recently, IS1595, a member of a new insertion sequence family, was described (44). IS1595 is present in high copy numbers in the genome of strains of $X$. citri pv. mangiferaeindicae, regardless of their country or host of isolation. However, it is absent or present at a very low copy number in the genome of most other Xanthomonas pathovars, including X. citri pv. anacardii (17). Therefore, IS1595-based typing techniques, such as IS1595-ligation-mediated PCR developed in the present study, have the capacity to generate complex and informative fingerprints for X. citri pv. mangiferaeindicae. An MLVA scheme which targets tandem repeats originally described in $X$. citri pv. citri, a genetically closely related bacterium, has the potential of subtyping $X$. citri pv. mangiferaeindicae with a high discriminatory power $(5,10)$.

On the basis of the reported usefulness of insertion sequences and tandem repeats as molecular epidemiology tools of several human bacterial pathogens, we evaluated how such markers would be appropriate for describing the genetic diversity of a worldwide strain collection of $X$. citri pv. mangiferaeindicae and for better understanding the epidemiology of this pathogen in future studies at different scales (from global surveillance to microgeographic epidemiology). These methods were compared with ones developed previously for this bacterium (RFLP and AFLP).

\section{MATERIALS AND METHODS}

Bacterial strains and DNA extraction. Strains of $X$. citri pv. mangiferaeindicae used in this study $(n=299)$ originated from 14 countries (i.e., most countries where the pathogen was reported) (18) and were previously characterized on the basis of pathogenicity assays or AFLP typing (4). The geographic origin and other characteristics of all $X$. citri pv. mangiferaeindicae strains are described in Supplementary Table 1. Nine Brazilian strains of $X$. citri $\mathrm{pv}$. anacardii, including the pathotype strain (PT), isolated from cashew (LA98, LA99, LA100, LA101, LA102, and LA103) or mango (CFBP 2912, CFBP 2913 ${ }^{\mathrm{PT}}$, and CFBP 2914), were used as reference strains (5).

Strains were stored at $-80^{\circ} \mathrm{C}$ on beads in cryovials (Microbank Prolab Diagnostics, Austin, TX) and also freeze dried for longterm storage. Cultures were grown routinely on medium consisting of $7 \mathrm{~g}$ of yeast extract, $7 \mathrm{~g}$ of peptone, $7 \mathrm{~g}$ of glucose, and $18 \mathrm{~g}$ of agar liter ${ }^{-1}$ plus propiconazole at $20 \mathrm{mg} \mathrm{liter}^{-1}$ at $28^{\circ} \mathrm{C}$. Some strains included in this study were deposited in the Collection Française de Bactéries Phytopathogènes (CFBP, INRA Angers, France); the Belgian Coordinated Collections of Microorganisms, University of Ghent, Belgium; and the National Collection of Plant Pathogenic Bacteria (CSL, York, UK).

Genomic DNA was extracted from bacteria using the DNeasy tissue kit (Qiagen, Courtaboeuf, France) following the manufacturer's instructions and DNA concentrations were estimated by fluorometry (TKO 100 Fluorometer; Hoefer, San Francisco). To test the reproducibility of the typing techniques, two independent DNA extractions were used for all strains. Strains CFBP 2933 and $X$. citri pv. citri 306 (13) were used as a control in each experiment for IS1595 ligation-mediated (LM)-PCR and MLVA, respectively.

LM-PCR targeting IS1595. Experiments were performed in 96-well plates in a GeneAmp PCR system 9700 thermocycler (Applied Biosystems, Courtaboeuf, France). Digestion and ligation were carried out simultaneously in a $20-\mu \mathrm{l}$ volume and contained $100 \mathrm{ng}$ of bacterial genomic DNA, 4.5 U of MspI (New England Biolabs/Ozyme, Saint Quentin en Yvelines, France), 1× bovine serum albumin, $50 \mathrm{mM}$ sodium chloride, $2.5 \mu \mathrm{M} \mathrm{MspI}$ adaptor, and $50 \mathrm{U}$ of T4 DNA ligase (New England Biolabs/ Ozyme, Saint Quentin en Yvelines, France) in 1× T4 DNA ligation buffer. The $M s p I$ adaptor was prepared by mixing the two oligonucleotides (5'-GACGATGAGTCCTGAG-3' and 5'-CGC
TCGGACTCATC-3') (Applied Biosystems) at equal concentrations for $5 \mathrm{~min}$ at $95^{\circ} \mathrm{C}$ and allowing them to cool to ambient temperature for $20 \mathrm{~min}$. Reactions were performed for $3 \mathrm{~h}$ at $37^{\circ} \mathrm{C}$ before enzyme inactivation at $65^{\circ} \mathrm{C}$ for $10 \mathrm{~min}$. Ligation products were diluted 10 -fold with high-performance liquid chromatography-grade water before PCR. The reactions were done in $20 \mu \mathrm{l}$ and contained $4 \mu \mathrm{l}$ of diluted ligation product, $2.5 \mathrm{mM}$ $\mathrm{MgCl}_{2}, 0.25 \mu \mathrm{M} \mathrm{MspI}$ primer (5'-GATGAGTCCTGAGCGG-3') and 6-FAM-5'-labeled IS1595 primer (5'-GTCAGGGCTAAT CAGG-3') (Applied Biosystems), $0.5 \mathrm{mM}$ each dNTP (New England Biolabs/Ozyme), $0.5 \mathrm{U}$ of Taq DNA polymerase (Goldstar Red; Eurogentec, Seraing, Belgium), in 1× Goldstar buffer. The inverted repeat region of a close variant of IS1595, present as a large copy number in the genome of $X$. oryzae pv. oryzae, is polymorphic. Therefore, some experiments were performed using an $\mathrm{MgCl}_{2}$ concentration of $5 \mathrm{mM}$ in order to enhance the stability of mismatched primers (23). Identical results were obtained whatever the $\mathrm{MgCl}_{2}$ concentration.

The following PCR conditions were used: initial extension to ligate the second strand of the adaptors at $72^{\circ} \mathrm{C}$ for $2 \mathrm{~min}$; then, a denaturation step at $94^{\circ} \mathrm{C}$ for $2 \mathrm{~min}$; followed by 35 cycles at $94^{\circ} \mathrm{C}$ for $45 \mathrm{~s}, 60^{\circ} \mathrm{C}$ for $1 \mathrm{~min}$, and $72^{\circ} \mathrm{C}$ for $1 \mathrm{~min}$; and a final extension step at $72^{\circ} \mathrm{C}$ for $10 \mathrm{~min}$. Samples were then prepared for capillary electrophoresis by adding $1 \mu \mathrm{l}$ of the final PCR product to $10.7 \mu \mathrm{l}$ of formamide and $0.3 \mu \mathrm{l}$ of LIZ500 DNA ladder (Applied Biosystems) as an internal standard. The mixture was then denatured for $5 \mathrm{~min}$ at $95^{\circ} \mathrm{C}$ and placed on ice for at least 5 min. Electrophoresis was performed in an ABI PRISM-3130XL Genetic Analyzer (Applied Biosystems) using performance optimized polymer POP-7 at $15,000 \mathrm{~V}$ for $\approx 20 \mathrm{~min}$ at $60^{\circ} \mathrm{C}$, with an initial injection of $46 \mathrm{~s}$. The fingerprints were analyzed visually using Genemapper software version 4.0 with the normalization option switched on (Applied Biosystems). Fragments with a size of 60 to $500 \mathrm{bp}$ were scored. Peaks with a height $>500$ relative fluorescence units (RFU) were scored. This threshold was found suitable for minimizing scoring discrepancies among DNA replicates in earlier studies $(4,8)$. This technique is subsequently referred to as IS1595-LM-PCR.

MLVA scheme. Detailed technical information is available in the work of Bui Thi Ngoc et al. (10). Fourteen primer pairs targeting single-locus alleles were designed from the full sequence of $X$. citri pv. citri strain 306 (13) and used in a multiplex PCR format (multiplex PCR kit; Qiagen). Most of these primers successfully produced amplicons from pathovars that are genetically related to $X$. citri pv. citri, including $X$. citri pv. mangiferaeindicae (10). One of each primer in the PCR mix was 5'-labeled with one of the following fluorescent dyes: 6-FAM, NED, PET, and VIC (Applied Biosystems). PCR amplifications were performed using the following conditions: $15 \mathrm{~min}$ at $95^{\circ} \mathrm{C}$ for hot start activation; followed by 25 cycles at $94^{\circ} \mathrm{C}$ for $30 \mathrm{~s}$, annealing at temperatures of 64 to $70^{\circ} \mathrm{C}$ for $90 \mathrm{~s}$, and $72^{\circ} \mathrm{C}$ for $90 \mathrm{~s}$; with a final extension step at $72^{\circ} \mathrm{C}$ for $30 \mathrm{~min}$. Capillary electrophoresis was performed as described above in an ABI PRISM-3130XL Genetic Analyzer (Applied Biosystems).

Data scoring and analysis. For IS1595-LM-PCR, the presence and absence of fragments were scored as a binary matrix. Dice dissimilarities were used as distances to construct a weighted neighbor-joining tree $(19,42)$ using the software $\mathrm{R}$ (version 2.10.0; R Development Core team) and the "cluster" version 1.12.1 and "ape" version 2.4-1 package (35). The robustness of the tree was assessed by bootstrap (1,000 resamplings). Metric multidimensional scaling (MDS) was also used to represent distances between strains, based on a Dice dissimilarity matrix. MDS transforms a distance matrix (which cannot be analyzed by eigen-decomposition) into a cross-product matrix and then solves the eigenvector problem to find the coordinates of individuals so that distortions to the distance matrix are minimized. As in principal component analysis, individuals are projected into $n$ 
dimensions (1). MDS was performed using the cmd-scale function in the R software.

For MLVA, integer numbers of tandem repeats were used as input data. Manhattan distances were calculated. MDS was performed as described above, based on the Manhattan distance matrix. The identification of MLVA types (i.e., groups of strains differing by one to three variable numbers of tandem repeats [VNTR] markers) was performed with eBURST v3 (16) at http://eburst.mlst.net/. Nei's unbiased gene diversity at each locus $\left(H_{d}\right)$ was calculated as $H_{d}=1-\Sigma x_{i}^{2}[n /(n-1)]$, with $x_{i}$ being the frequency of $i$ th allele and $n$ the total number of strains.

Genetic diversity and congruence among genotyping techniques. The discriminatory power of each typing system was calculated using Hunter's single numerical index of discrimination (D) (22). This analysis was performed on our collection $(n=299)$ typed by AFLP (4), IS1595-LM-PCR, and MLVA (this study). The correlations between distance matrices were tested globally by computing the Kendall's coefficient of concordance (W) among the distance matrices through a permutation test (9,999 permutations) with the "CADM.global" function (11) of the ape package in R software. Kendall's W is a nonparametric statistic (no assumptions are made on the probability distribution of the values) that evaluates congruence among multiple rating systems, with $\mathrm{W}$ ranging from 0 (no agreement) to 1 (complete agreement) (25). The concordant and discordant distance matrices in the group were identified by Mantel tests that were carried out by using the "CADM.post" function in ape (11). The Holm's correction method for multiple testing was applied to the list of $P$ values produced in the a posteriori Mantel tests. Similar analyses were conducted on a smaller $(n=56)$ set of strains for which RFLP data using IS1595 and avrXa10 as probe were available (17).

\section{RESULTS}

LM-PCR targeting IS1595. Only markers that were reproducibly scored were kept in the data set for further analysis. Most cases where discrepancies were found among DNA replicates corresponded to double peaks or weakly amplified fragments (height $\leq 700$ RFU). Double peaks were characterized by no return to base line in between peaks, with respective sizes differing by one nucleotide. An increase of $\leq 30 \mathrm{~min}$ of the final extension step had no effect on these double peaks and they were scored as a single fragment. Weakly amplified fragments may result from copies of IS1595 with an inverted repeat sequence differing slightly from that of the primer.

No complex fingerprints (zero or one faint band was scored) were produced with $X$. citri pv. anacardii. In contrast, 68 to 73 bands were scored per strain of $X$. citri pv. mangiferaeindicae, and 23 band positions (28\%) were polymorphic. This allowed the identification of 29 haplotypes among the 299 strains studied (Table 1). The representation of axes 1 and 2 of the MDS described $87.0 \%$ of the total variation. The population structure derived from the IS1595-LM-PCR analysis was partly consistent with that previously described by RFLP (Fig. 1). Some strains classified as RFLP groups A and B were not clearly separated based on IS1595-LM-PCR, although no strain from these two RFLP groups shared identical IS1595-LM-PCR fingerprints. Some strains isolated in Reunion island from mango (RFLP group $\mathrm{C}_{1}$ ) or Brazilian pepper (Schinus terebinthifolius Raddi; RFLP group D) were not clearly separated, consistent with previous studies. IS1595-LM-PCR allowed subtyping of some RFLP group $\mathrm{A}$ and group $\mathrm{C} 1$ strains (Fig. 1). When a neighbor-joining tree representation was used, all branches were characterized by bootstrap values $\leq 70 \%$, suggesting a low potential of IS1595-LMPCR for robust analysis of genetic diversity (data not shown).

MLVA scheme. $X$. citri pv. mangiferaeindicae strains yielded reproducible amplicons from 12 of the 14 VNTR markers developed for $X$. citri pv. citri. In contrast, amplicons were obtained only from four (XL4, XL5, XL10, and XL11) loci for all strains of $X$. citri pv. anacardii. Amplicons were also produced for the XL3 and XL9 loci for all strains of $X$. citri pv. anacardii but CFBP 2912 and CFBP 2913. In total, four haplotypes were identified within the $X$. citri pv. anacardii collection. Strains

TABLE 1. Information on the Xanthomonas citri pv. mangiferaeindicae haplotypes identified by IS1595 ligation-mediated polymerase chain reaction and the related multilocus variable number of tandem repeats analysis (MLVA) haplotypes

\begin{tabular}{|c|c|c|c|}
\hline IS1595 haplotype number & $\begin{array}{c}\text { Number of } \\
\text { strains }\end{array}$ & Location of isolation & $\begin{array}{l}\text { Number of related } \\
\text { MLVA haplotypes }\end{array}$ \\
\hline 1 & 2 & Reunion Island & 2 \\
\hline 2 & 2 & Reunion Island, South Africa & 2 \\
\hline 4 & 2 & Mauritius & 2 \\
\hline 5 & 2 & Reunion Island & 2 \\
\hline 6 & 2 & Rodrigues Island & 1 \\
\hline 7 & 1 & South Africa & 1 \\
\hline 10 & 6 & Australia & 5 \\
\hline 11 & 2 & Australia & 2 \\
\hline 12 & 3 & Australia & 3 \\
\hline 13 & 4 & Reunion Island & 4 \\
\hline 14 & 52 & Mauritius, Reunion Island & 40 \\
\hline 15 & 12 & Reunion Island & 9 \\
\hline 16 & 1 & Reunion Island & 1 \\
\hline 22 & 1 & Reunion Island & 1 \\
\hline 23 & 6 & Reunion Island & 4 \\
\hline 24 & 2 & Philippines & 2 \\
\hline 25 & 169 & Comoros, Japan, Mauritius, New Caledonia, Reunion Island, South Africa, Taiwan & 134 \\
\hline 26 & 1 & Thailand & 1 \\
\hline 27 & 1 & India & 1 \\
\hline 28 & 1 & Reunion Island & 1 \\
\hline 29 & 9 & Japan & 4 \\
\hline
\end{tabular}


originating from cashew (a single haplotype) and mango (three haplotypes) were distinguishable based on data derived from the XL5 and XL11 loci. Given the low number of VNTR markers successfully amplified for $X$. citri pv. anacardii, these strains were not considered for further analysis. Among strains of $X$. citri pv. mangiferaeindicae, 231 haplotypes were detected among the 299 strains when data from the 12 markers were pooled, with allele numbers per locus ranging from 1 (XL10) to 28 (XL4) (Supplementary Table 2). Most often, loci for which high repeat numbers were recorded had higher diversity indices. MLVA had the ability to subtype IS1595-LM-PCR haplotypes (Table 1). The representation of axes 1 and 2 of the MDS described $87.6 \%$ of the total variation. The population structure derived from MLVA was mostly consistent with that previously described by RFLP (Fig. 2). Strains isolated in Reunion island from mango (RFLP group $\mathrm{C}_{1}$ ) or Brazilian pepper ( $S$. terebinthifolius Raddi, RFLP group D) were not clearly separated, consistent with previous studies (AFLP) and IS1595-LM-PCR data (this study). Among strains isolated from mango, MLVA profiles that most noticeably departed from the RFLP classification concerned two strains (JP682 and JP683) originating from India and previously classified as RFLP group B. Based on MLVA data, these strains clustered with RFLP group A and C strains, respectively (Fig. 2A). The representation of axes 1 and 3 of the MDS, which accounted for $79.5 \%$ of the total variation, confirmed the atypical placement of these two strains (Fig. 2B). Moreover, a cluster of six strains not previously characterized by RFLP and distinct from other strains (Fig. 2A, upper right part of the MDS plot) was identified. These strains originated from two sites in the Mpumalanga province of South Africa. The representation of axes 1 and 3 of the MDS (Fig. 2B) suggested that these strains were most closely related to group A strains, consistent with previous data derived from AFLP.

Strains with the same MLVA profile were primarily isolated from a single site or from spatially close sites during the same year or over intervals of up to 2 years. However, three cases were identified in which strains from remote areas shared the same MLVA profile. One involved two strains isolated from Reunion

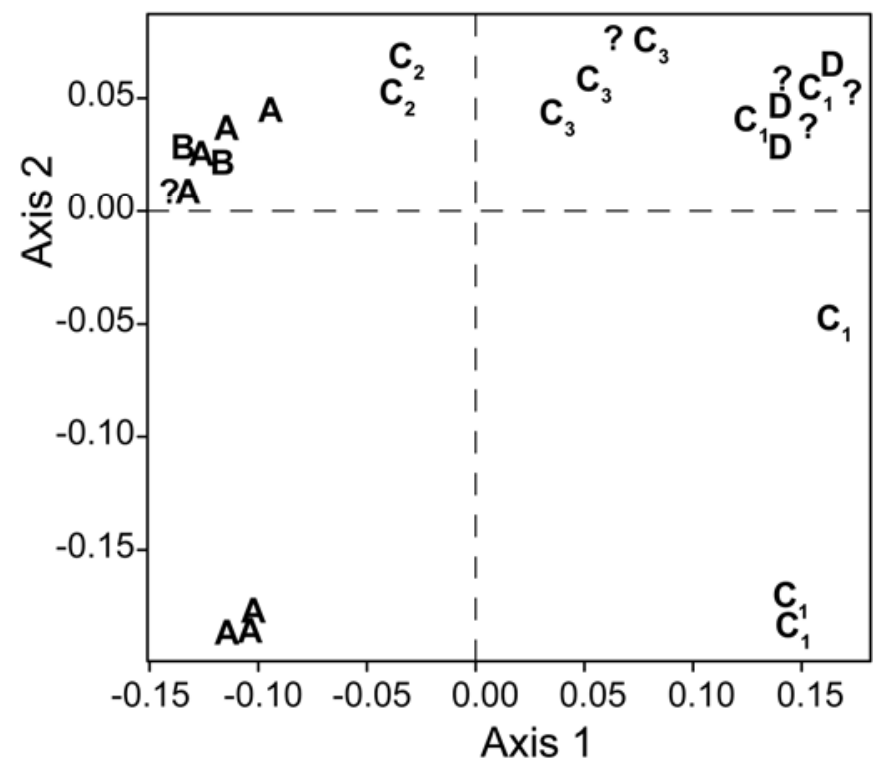

Fig. 1. Dice dissimilarities among 29 haplotypes of Xanthomonas citri pv. mangiferaeindicae based on IS1595 ligation-mediated polymerase chain reaction data represented by multidimensional scaling. Axes 1 and 2 represented $87.0 \%$ of the total variation. Corresponding restriction fragment length polymorphism (RFLP) groups $(4,17)$ are indicated. Three RFLP groups (A, B, and $\mathrm{C}$ ) contained strains isolated from mango, whereas strains classified in RFLP group D originated from Brazilian pepper; ? indicates strains for which RFLP data was unavailable. island and Mauritius, respectively, within a 1-year interval. Two cases concerned strains isolated the same year from sites in South Africa that were 50 and $>500 \mathrm{~km}$ apart, respectively. An eBURST analysis of the 231 MLVA types yielded 28 clonal complexes and 163 singletons. Twenty-two of the clonal complexes contained strains for which precise information was available. When the three above-mentioned cases were taken apart, all clonal complexes contained strains collected from a single site over one or two consecutive years.

Comparative genetic diversity. The discriminatory power of AFLP, IS1595-LM-PCR, and MLVA was determined and compared by calculating Hunter's single numerical index of discrimination (D) of 299 strains typed by all three methods. MLVA differentiated 231 haplotypes and showed the best level of dis-
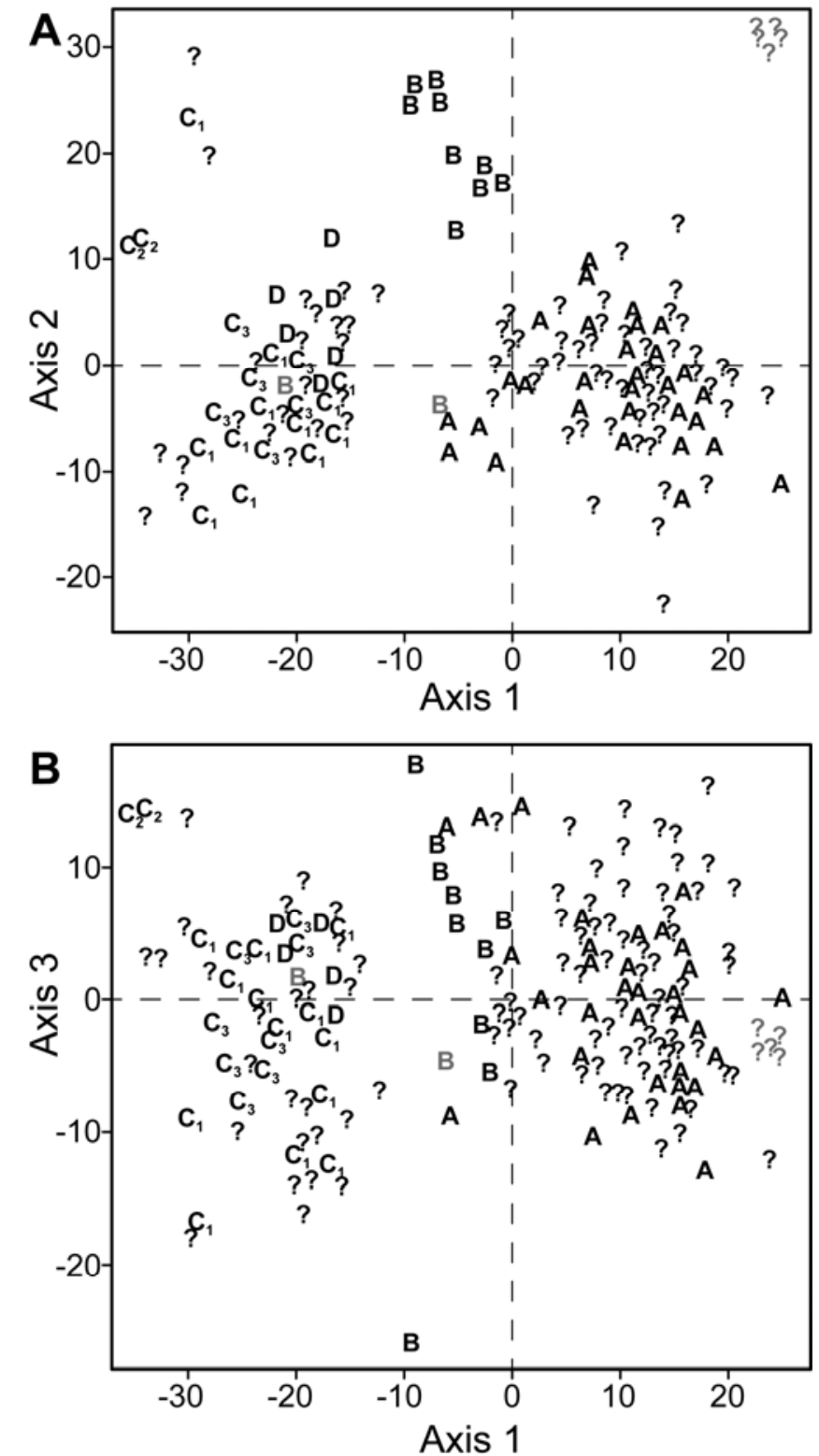

Fig. 2. Manhattan distances among 231 haplotypes of Xanthomonas citri pv. mangiferaeindicae based on multilocus variable number of tandem repeats analysis (MLVA) data represented by multidimensional scaling. Corresponding restriction fragment length polymorphism (RFLP) groups $(4,17)$ are indicated. A, Representation of axes 1 and 2 (87.6\% of the total variation); $\mathbf{B}$, representation of axes 1 and 3 (79.5\% of the total variation). Three RFLP groups (A, B, and C) contained strains isolated from mango, whereas strains classified in RFLP group D originated from Brazilian pepper; ? indicates strains for which RFLP data was unavailable. Comments are available in the text for strains highlighted in gray. 
crimination, with a D value of 0.996. AFLP markers distinguished 125 haplotypes $(\mathrm{D}=0.945)$ while IS1595-LM-PCR only distinguished 29 haplotypes $(\mathrm{D}=0.653)$. The $\mathrm{W}$ statistics $(\mathrm{W}=$ $0.7414)$ globally indicated congruence among the three genotyping techniques $(P=0.0001)$. A posteriori comparisons based on Mantel tests gave pairwise correlation values between distances among haplotypes obtained for AFLP versus IS1595-LMPCR, AFLP versus MLVA, and IS1595-LM-PCR versus MLVA of $0.701,0.584$, and 0.553 , respectively, and these were congruent to each other $(P=0.0003)$. Similarly, the analysis performed on a set of 56 strains indicated overall congruence among the five genotyping techniques ( $\mathrm{W}=0.5552 ; P=0.0001$ ). A posteriori comparisons based on Mantel tests showed that all pairs of distance matrices were congruent to each other with a $P$ value of 0.0005 (Table 2).

\section{DISCUSSION}

Given that bacterial canker is a major threat for the worldwide mango industry, there is clearly a need for fast and accurate pathovar identification techniques that do not require pathogenicity assays. Indeed, the availability of such techniques would be very helpful to diagnosticians. Moreover, there is a need for further knowledge of the biology and epidemiology of $X$. citri pv. mangiferaeindicae, because several important issues are still only partially understood (such as the biological significance of some inoculum sources identified for this pathosystem or of alternative host species, and so on) (18). For example, it was recently shown that asymptomatic $X$. citri pv. mangiferaeindicae populations associated with mango leaves are primarily endophytic and may represent latent infections rather than epiphytic survival (38). Therefore, this calls into question the significance of epiphytic populations as a primary inoculum source for outbreaks (38). A thorough evaluation of the putative role of Brazilian pepper as an alternative host species is also required (18). Molecular markers with very high discriminatory power have the potential to address such questions (48). To date, molecular epidemiology of bacterial pathogens has primarily been used to further our understanding of outbreaks and transmission routes of human and animal pathogens $(2,14,45,50,52)$. In the present study, we evaluated two genotyping techniques derived from recently described molecular markers, an insertion sequence (44) and tandem repeats developed for the closely related $X$. citri pv. citri (10).

LM-PCR targeting IS1595 (IS1595-LM-PCR) produced complex fingerprints for $X$. citri pv. mangiferaeindicae, with $\approx 70$ amplicons. However, it produced no or a low number of weak amplicons for $X$. citri pv. anacardii, a bacterium morphologically indistinguishable from pv. mangiferaeindicae when cultured (37). Compared with the pathogenicity tests often used for routine diagnosis or other genotyping that were previously developed (RFLP, AFLP, and MLSA) for this group of Anacardiaceae pathogens, IS1595-LM-PCR is less labor intensive. IS1595-LM-PCR can produce fingerprints with a single PCR assay preceded by a short restriction-ligation step. Therefore, this technique could be helpful for identifying bacterial colonies recovered from isolation attempts of the causal agent of MBC reliably and more quickly. IS1595-LM-PCR revealed less polymorphism than AFLP. The high similarity of fingerprints obtained by IS1595-LM-PCR, regardless of the country or host of origin of the bacterial isolates, suggests that data are easy to interpret for identification purposes. IS1595-LM-PCR can clearly distinguish between the two Xanthomonas pathovars that are pathogenic to mango, although it is unable to identify $X$. citri pv. anacardii clearly. When the latter bacterium is suspected, other genotyping techniques, such as AFLP or MLSA (5), should be used for confirmation.

Unlike several other insertion sequence elements $(33,46)$, we suggest that IS1595 has little potential for molecular epidemiology studies. Our hypothesis is that the low levels of polymorphism may be linked to the large number of copies of IS1595 present in $X$. citri pv. mangiferaeindicae genomes, possibly caused by the saturation of specific insertion sites or by mechanisms of transposition self-regulation, which may reduce the mobility of ISs to avoid genome invasion $(28,32)$. This element may have played a role in the early steps of the evolution of $X$. citri pv. mangiferaeindicae, by facilitating horizontal gene transfer between bacterial populations, creating gene disruptions, or modulating gene expression (i.e., enhancing its adaptive capacities) (29) and leading to the contemporary genotypes (in which a relative stability for the content and position of IS1595 in the genomes has been observed).

The present study showed that most VNTR markers developed for $X$. citri pv. citri (10) are useful for genotyping X. citri pv. mangiferaeindicae. In contrast with IS1595-LM-PCR and consistent with previous data (9), MLVA yielded a very large genetic diversity among strains of this bacterium. With a Hunter's D index close to 1 , MLVA clearly has the ability to discriminate $X$. citri pv. mangiferaeindicae at the strain level. According to the results obtained for the Kendall's coefficient of concordance and Mantel tests, the genetic similarities derived from MLVA data were significantly congruent to those derived from IS1595-LMPCR (this study), RFLP (17), and, interestingly, AFLP (4), a technique that accurately reflects DNA relatedness among Xanthomonas strains (39). Despite the propensity of VNTR markers for homoplasy, the population structure of $X$. citri pv. mangiferaeindicae as highlighted by MLVA-based typing provided an appropriate representation of the genetic structure of the pathovar previously revealed by RFLP (17) or AFLP (4). This result may be explained by the relatively large range of molecular clock speeds of the loci used in our MLVA scheme. The loci with a lower clock speed made it possible to build a structure representative of the one revealed by AFLP.

The high discriminatory power of MLVA makes it possible to conduct molecular epidemiology analyses at relatively small spatial or temporal scales. The number of tandem repeat units per locus is a highly robust strain-defining parameter (48). MLVA could be useful for tracing haplotypes in field studies and for investigating inoculum sources associated with outbreaks. MLVA was highly suitable for the discrimination of populations of bacteria with a low genetic diversity, such as those causing anthrax (24). In our study, eBURST analyses produced a large

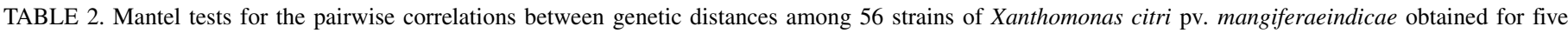
genotyping techniques ${ }^{\mathrm{a}}$

\begin{tabular}{|c|c|c|c|c|}
\hline Technique & MLVA & AFLP & IS1595-RFLP & avrXa10-RFLP \\
\hline IS1595-LM-PCR & $0.3424 * * * *$ & $0.4039 * * * *$ & $0.4693 * * * *$ & $0.4181 * * * *$ \\
\hline MLVA & 1.0000 & $0.4980 * * * *$ & $0.4054 * * * *$ & $0.3775 * * * *$ \\
\hline AFLP & $\ldots$ & 1.0000 & $0.5245^{* * * * *}$ & $0.4921 * * * *$ \\
\hline IS 1595-RFLP & $\ldots$ & $\ldots$ & 1.0000 & $0.5093 * * * *$ \\
\hline avrXa10-RFLP & $\ldots$ & $\ldots$ & $\ldots$ & 1.0000 \\
\hline
\end{tabular}

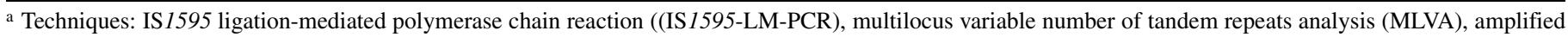
fragment length polymorphism (AFLP), IS1595 restriction fragment length polymorphism (RFLP), and avrXa10-RFLP. AFLP and RFLP data were published previously $(4,17) ; * * * *$ indicates $P=0.0005$. 
number of singletons or small clonal complexes consistent with the features of our bacterial collection (which primarily contained strains that probably had no epidemiological link). Strains that shared identical MLVA profiles or that belonged to the same clonal complex most often originated from the same site in the same year or within a 2-year interval. This strongly suggests epidemiological linkage. However, in three cases, these were isolated from geographically remote areas and, therefore, suggest long-distance migration, possibly through diseased or contaminated propagative plant material. The first two cases concerned South African strains isolated from sites that were $\leq 500 \mathrm{~km}$ apart. The third case involved strains that were isolated within a 1-year interval from Mauritius and Reunion island, two neighboring islands in the South West Indian Ocean region, where uncontrolled exchanges of plant material are known to occur. These results further confirm the potential of MLVA to assess epidemiological linkage among isolates.

\section{ACKNOWLEDGMENTS}

The European Union (FEOGA, FEDER), Conseil Régional de La Réunion and CIRAD provided financial support. We thank B. Q. Manicom, S. Benimahdu, S. Gnanamanickam, J. Brinon, P. Fahy, M. Moffett, J. Moll, C. d'Ursel, W. Wu for providing us with bacterial strains; and C. Boyer, A. W. Grondin, and V. Ledoux for their technical assistance.

\section{LITERATURE CITED}

1. Abdi, H. 2007. Metric multidimensional scaling (MDS): Analyzing distance matrices. Pages 1-13 in: Encyclopedia of Measurement and Statistics. N. Salkind, ed. Sage, Thousand Oaks, CA.

2. Achtman, M. 2002. A phylogenetic perspective on molecular epidemiology. Pages 485-509 in: Molecular Medical Microbiology. M. Sussman, ed. Academic Press, London.

3. Adhikari, T. B., Vera Cruz, C. M., Zhang, Q., Nelson, R. J., Skinner, D. Z., Mew, T. W., and Leach, J. E. 1995. Genetic diversity of Xanthomonas oryzae pv. oryzae in Asia. Appl. Environ. Microbiol. 61:966-971.

4. Ah-You, N., Gagnevin, L., Chiroleu, F., Jouen, E., Neto, J. R., and Pruvost, O. 2007. Pathological variations within Xanthomonas campestris pv. mangiferaeindicae support its separation into three distinct pathovars that can be distinguished by amplified fragment length polymorphism. Phytopathology 97:1568-1577.

5. Ah-You, N., Gagnevin, L., Grimont, P. A. D., Brisse, S., Nesme, X., Chiroleu, F., Bui Thi Ngoc, L., Jouen, E., Lefeuvre, P., Vernière, C., and Pruvost, O. 2009. Polyphasic characterization of xanthomonads pathogenic to Anacardiaceae and their relatedness to different Xanthomonas species. Int. J. Syst. Evol. Microbiol. 59:306-318.

6. Ardales, E. Y., Leung, H., Vera Cruz, C. M., Mew, T. W., Leach, J. E., and Nelson, R. J. 1996. Hierarchical analysis of spatial variation of the rice bacterial blight pathogen across diverse agroecosystems in the Philippines. Phytopathology 86:241-252.

7. Boudon, S., Manceau, C., and Notteghem, J. L. 2005. Structure and origin of Xanthomonas arboricola pv. pruni populations causing bacterial spot of stone fruit trees in Western Europe. Phytopathology 95:1081-1088.

8. Bui Thi Ngoc, L., Vernière, C., Belasque, J., Vital, K., Boutry, S., Gagnevin, L., and Pruvost, O. 2008. Ligation-mediated PCR, a fast and reliable technique for insertion sequence-based typing of Xanthomonas citri pv. citri. FEMS Microbiol. Lett. 288:33-39.

9. Bui Thi Ngoc, L., Vernière, C., Jarne, P., Brisse, S., Guérin, F., Boutry, S., Gagnevin, L., and Pruvost, O. 2009. From local surveys to global surveillance: Three high throughput genotyping methods for the epidemiological monitoring of Xanthomonas citri pv. citri pathotypes. Appl. Environ. Microbiol. 75:1173-1184.

10. Bui Thi Ngoc, L., Vernière, C., Vital, K., Guérin, F., Gagnevin, L., Brisse, S., Ah-You, N., and Pruvost, O. 2009. Fourteen minisatellite markers for population studies of the citrus canker bacterium, Xanthomonas citri pv. citri. Mol. Ecol. Res. 9:125-127.

11. Campbell, V., Legendre, P., and Lapointe, F. J. 2009. Assessing congruence among ultrametric distance matrices. J. Classif. 26:103-117.

12. Ciammaruconi, A., Grassi, S., De Santis, R., Faggioni, G., Pittiglio, V., D'Amelio, R., Carattoli, A., Cassone, A., Vergnaud, G., and Lista, F. 2008. Fieldable genotyping of Bacillus anthracis and Yersinia pestis based on 25-loci multi locus VNTR analysis. BMC Microbiol. 8:doi: $10.1186 / 1471-2180-8-21$.
13. Da Silva, A. C., Ferro, J. A., Reinach, F. C., Farah, C. S., Furlan, L. R., Quaggio, R. B., Monteiro-Vitorello, C. B., Van Sluys, M. A., Almeida, N. F., Alves, L. M., Do Amaral, A. M., Bertolini, M. C., Camargo, L. E., Camarotte, G., Cannavan, F., Cardozo, J., Chambergo, F., Ciapina, L. P., Cicarelli, R. M., Coutinho, L. L., Cursino-Santos, J. R., El-Dorry, H., Faria, J. B., Ferreira, A. J., Ferreira, R. C., Ferro, M. I., Formighieri, E. F., Franco, M. C., Greggio, C. C., Gruber, A., Katsuyama, A. M., Kishi, L. T., Leite, R. P., Lemos, E. G., Lemos, M. V., Locali, E. C., Machado, M. A., Madeira, A. M., Martinez-Rossi, N. M., Martins, E. C., Meidanis, J., Menck, C. F., Miyaki, C. Y., Moon, D. H., Moreira, L. M., Novo, M. T., Okura, V. K., Oliveira, M. C., Oliveira, V. R., Pereira, H. A., Rossi, A., Sena, J. A., Silva, C., De Souza, R. F., Spinola, L. A., Takita, M. A., Tamura, R. E., Teixeira, E. C., Tezza, R. I., Trindade dos Santos, M., Truffi, D., Tsai, S. M., White, F. F., Setubal, J. C., and Kitajima, J. P. 2002. Comparison of the genomes of two Xanthomonas pathogens with differing host specificities. Nature 417:459-463.

14. De Meeus , T., McCoy, K. D., Prugnolle, F., Chevillon, C., Durand, P., Hurtrez-Bousses, S., and Renaud, F. 2007. Population genetics and molecular epidemiology or how to "débusquer la bête". Infect. Genet. Evol. 7:308-332.

15. Dye, D. W., Bradbury, J. F., Goto, M., Hayward, A. C., Lelliott, R. A., and Schroth, M. N. 1980. International standards for naming pathovars of phytopathogenic bacteria and a list of pathovar names and pathotype strains. Rev. Plant Pathol. 59:153-168.

16. Feil, E. J., Li, B. C., Aanensen, D. M., Hanage, W. P., and Spratt, B. G. 2004. eBURST: Inferring patterns of evolutionary descent among clusters of related bacterial genotypes from multilocus sequence typing data. J. Bacteriol. 186:1518-1530.

17. Gagnevin, L., Leach, J. E., and Pruvost, O. 1997. Genomic variability of the Xanthomonas pathovar mangiferaeindicae, agent of mango bacterial black spot. Appl. Environ. Microbiol. 63:246-253.

18. Gagnevin, L., and Pruvost, O. 2001. Epidemiology and control of mango bacterial black spot. Plant Dis. 85:928-935.

19. Gascuel, O. 1997. Concerning the NJ algorithm and its unweighted version UNJ. Pages 149-171 in: Mathematical Hierarchies and Biology. B. Mirkin, F. R. McMorris, F. Roberts, and A. Rzhetsky, eds. American Mathematical Society, Providence, RI.

20. George, M. L. C., Bustamam, M., Cruz, W. T., Leach, J. E., and Nelson, R. J. 1997. Movement of Xanthomonas oryzae pv. oryzae in southeast Asia detected using PCR-based DNA fingerprinting. Phytopathology 87:302-309.

21. Humeau, L., Roumagnac, P., Picard, Y., Robène-Soustrade, I., Chiroleu, F., Gagnevin, L., and Pruvost, O. 2006. Quantitative and molecular epidemiology of bacterial blight of onion in seed production fields. Phytopathology 96:1345-1354.

22. Hunter, P. R., and Gaston, M. A. 1988. Numerical index of the discriminatory ability of typing systems: An application of Simpson's index of diversity. J. Clin. Microbiol. 26:2465-2466.

23. Innis, M. A., Gelfand, D. H., and Sninsky, J. J. 1999. PCR Applications: Protocols for Functional Genomics. Academic Press, San Diego, London, Boston, New York, Sydney, Tokyo, Toronto.

24. Keim, P., Van Ert, M. N., Pearson, T., Vogler, A. J., Huynh, L. Y., and Wagner, D. M. 2004. Anthrax molecular epidemiology and forensics: Using the appropriate marker for different evolutionary scales. Infect. Genet. Evol. 4:205-213.

25. Kendall, M. G., and Babington-Smith, B. 1939. The problem of $\mathrm{m}$ rankings. Ann. Math. Stat. 10:275-287.

26. Kotlowski, R., Shamputa, I. C., El Aila, N. A., Sajduda, A., Rigouts, L., Van Deun, A., and Portaels, F. 2004. PCR-based genotyping of Mycobacterium tuberculosis with new GC-rich repeated sequences and IS6110 inverted repeats used as primers. J. Clin. Microbiol. 42:372-377.

27. Li, W., Song, Q., Brlansky, R. H., and Hartung, J. S. 2007. Genetic diversity of citrus bacterial canker pathogens preserved in herbarium specimens. Proc. Natl. Acad. Sci. USA 104:18427-18432.

28. Mahillon, J., and Chandler, M. 1998. Insertion sequences. Microbiol. Mol. Biol. Rev. 62:725-774

29. Mahillon, J., Leonard, C., and Chandler, M. 1999. IS elements as constituents of bacterial genomes. Res. Microbiol. 150:675-687.

30. Malorny, B., Junker, E., and Helmuth, R. 2008. Multi-locus variablenumber tandem repeat analysis for outbreak studies of Salmonella enterica serotype Enteritidis. BMC Microbiol. 8:doi: 10.1186/1471-21808-84.

31. Manicom, B. Q., and Wallis, F. M. 1984. Further characterization of Xanthomonas campestris pv. mangiferaeindicae. Int. J. Syst. Bacteriol. 34:77-79.

32. Nagy, Z., and Chandler, M. 2004. Regulation of transposition in bacteria. Res. Microbiol. 155:387-398.

33. Owen, R. J., Peters, T. M., Varea, R., Teare, E. L., and Saverymuttu, S. 2001. Molecular epidemiology of Helicobacter pylori in England: Prevalence of cag pathogenicity island markers and IS605 presence in 
relation to patient age and severity of gastric disease. FEMS Immunol. Med. Microbiol. 30:65-71.

34. Palittapongarnpim, P., Chomyc, S., Fanning, A., and Kunimoto, D. 1993. DNA fingerprinting of Mycobacterium tuberculosis isolates by ligationmediated polymerase chain reaction. Nucleic Acids Res. 21:761-762.

35. Paradis, E., Claude, J., and Strimmer, K. 2004. APE: Analyses of phylogenetics and evolution in R language. Bioinformatics 20:289-290.

36. Prakash, O., and Misra, A. K. 1992. Important diseases of mango and their effect on production. Biol. Mem. 18:39-55.

37. Pruvost, O., Couteau, A., Perrier, X., and Luisetti, J. 1998. Phenotypic diversity of Xanthomonas sp. mangiferaeindicae. J. Appl. Microbiol. $84: 15-24$

38. Pruvost, O., Savelon, C., Boyer, C., Chiroleu, F., Gagnevin, L., and Jacques, M. A. 2009. Populations of Xanthomonas citri pv. mangiferaeindicae from asymptomatic mango leaves are primarily endophytic. Microbiol. Ecol. 58:170-178.

39. Rademaker, J. L. W., Hoste, B., Louws, F. J., Kersters, K., Swings, J., Vauterin, L., Vauterin, P., and De Bruijn, F. J. 2000. Comparison of AFLP and rep-PCR genomic fingerprinting with DNA-DNA homology studies: Xanthomonas as a model system. Int. J. Syst. Evol. Microbiol. 50:665-677.

40. Reisig, F., Kremer, K., Amthor, B., Van Soolingen, D., and Haas, W. H. 2005. Fast ligation-mediated PCR, a fast and reliable method for IS6110based typing of Mycobacterium tuberculosis complex. J. Clin. Microbiol. 43:5622-5627.

41. Restrepo, S., and Verdier, V. 1997. Geographical differentiation of the population of Xanthomonas axonopodis pv. manihotis in Colombia. Appl. Environ. Microbiol. 63:4427-4434.

42. Saitou, N., and Nei, M. 1987. The neighbor-joining method: A new method for reconstructing phylogenetic trees. Mol. Biol. Evol. 4:406-425.

43. Schimmer, B., Nygard, K., Eriksen, H. M., Lassen, J., Lindstedt, B. A., Brandal, L. T., Kapperud, G., and Aavitsland, P. 2008. Outbreak of haemolytic uraemic syndrome in Norway caused by stx2-positive Escherichia coli O103:H25 traced to cured mutton sausages. BMC Infect. Dis. 8:doi:10.1186/1471-2334-8-41.

44. Siguier, P., Gagnevin, L., and Chandler, M. 2009. The new IS 1595 family, its relation to IS 1 and the frontier between insertion sequences and transposons. Res. Microbiol. 160:232-241.

45. Speert, D. P. 2002. Molecular epidemiology of Pseudomonas aeruginosa. Front. Biosci. 7:E354-E361.

46. Stanley, J., and Saunders, N. 1996. DNA insertion sequences and the molecular epidemiology of Salmonella and Mycobacterium. J. Med. Microbiol. 45:236-251.

47. Supply, P., Lesjean, S., Savine, E., Kremer, K., Van Soolingen, D., and Locht, C. 2001. Automated high-throughput genotyping for study of global epidemiology of Mycobacterium tuberculosis based on mycobacterial interspersed repetitive units. J. Clin. Microbiol. 39:35633571.

48. Van Belkum, A. 2007. Tracing isolates of bacterial species by multi locus variable number of tandem repeat analysis (MLVA). FEMS Immunol. Med. Microbiol. 49:22-27.

49. Van Belkum, A., Struelens, M., De Visser, A., Verbrugh, H., and Tibayrenc, M. 2001. Role of genomic typing in taxonomy, evolutionary genetics, and microbial epidemiology. Clin. Microbiol. Rev. 14:547-560.

50. Van Soolingen, D. 2001. Molecular epidemiology of tuberculosis and other mycobacterial infections: Main methodologies and achievements. J. Int. Med. 249:1-26.

51. Vera Cruz, C. M., Ardales, E. Y., Skinner, D. Z., Talag, J., Nelson, R. J., Louws, F. J., Leung, H., Mew, T. W., and Leach, J. E. 1996. Measurement of haplotypic variation in Xanthomonas oryzae pv. oryzae within a single field by rep-PCR and RFLP analyses. Phytopathology 86:1352-1359.

52. Vogel, U., and Claus, H. 2003. Molecular epidemiology of Neisseria meningitidis. Front. Biosci. 8:E14-E22. 